\title{
運動時におけるリアルタイムでの心拍変動解析に基づく至適運動強度の決定
}

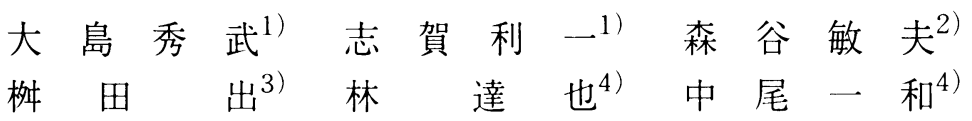

\section{DETERMINATION OF OPTIMAL EXERCISE INTENSITY BASED ON REAL-TIME ANALYSIS OF HEART RATE VARIABILITY DURING EXERCISE}

\author{
Yoshitake Oshima, Toshikazu Shiga, Toshio Moritani, Izuru Masuda, \\ TATSUYy HAYASHI and KAZUWA NAKAO
}

\begin{abstract}
The purpose of the present study was to develop a new method that enables individualized determination of the optimal exercise intensity for health promotion. Our study was based on the following observations: (1) physical activity at ventilatory threshold (VT) has been useful for enhancing physical fitness and even improving medical conditions such as heart failure, hypertension and diabetes, (2) exercise intensity at VT is characterized by suppressed vagal activity, and (3) vagal activity can be evaluated by analyzing heart rate variability (HRV). In the first study we defined a criteria for determining the exercise intensity corresponding to VT using HRV analysis (heart rate variability threshold, $\mathrm{T}_{H R V}$ ). In 16 normal subjects, a time series of ECG RR interval were recorded and the means of the sum of the squared differences in successive RR intervals (MSSDs) were calculated during a ramp exercise test with a cycle ergometer. Based on the values of MSSD and the differences in successive MSSDS $\left(\triangle M\right.$ MSD) at the intensity of VT, we defined the criteria of $T_{I I R V}$ as follows : $\mathrm{MSSD}<25 \mathrm{msec}^{2}$ and $\triangle \mathrm{MSSD}<6 \mathrm{msec}^{2}$. Another exercise test with a cycle ergo-meter was performed to evaluate the relationship between $T_{\text {IIRV }}$ and VT in 63 normal subjects. Heart rate (HR) and oxygen uptake $\left(\dot{\mathrm{VO}}_{2} / \mathrm{wt}\right)$ at $\mathrm{T}_{\mathrm{HRV}}$ were $111.8 \pm 13.2 \mathrm{beats} / \mathrm{min}$ and $15.2 \pm 4.4 \mathrm{ml} / \mathrm{kg} / \mathrm{min}$, and $\mathrm{HR}$ and $\dot{\mathrm{VO}}_{2} /$ wt at $\mathrm{VT}$ were $116.2 \pm 11.6$ beats $/ \mathrm{min}$ and $16.5 \pm 3.7 \mathrm{ml} / \mathrm{kg} / \mathrm{min}$, respectively. There was a significant correlation between $\mathrm{T}_{\mathrm{HRV}}$ and $\mathrm{VT}\left(\mathrm{HR}: \mathrm{r}=0.82, \mathrm{p}<0.001, \dot{\mathrm{VO}}_{2} / \mathrm{wt}: \mathrm{r}=0.88, \mathrm{p}<\right.$ $0.001)$. Thus, $\mathrm{T}_{\mathrm{HRV}}$ and VT provided almost identical exercise intensities. As a result, we propose that, similar to VT, $\mathrm{T}_{\mathrm{HRV}}$ can be used as an indicator of the optimal exercise intensity suitable for health promotion in normal subjects.
\end{abstract}

(Jpn. J. Phys. Fitness Sports Med. 2003, $52: 295 \sim 304$ )

key word : exercise intensity, heart rate variability, ventilatory threshold

I. 目的

近年，乳酸性作業閾値 (Lactate Threshold, LT) あるいは換気性作業閯值 (Ventilatory Threshold,
VT)の強度での運動が健康の維持・増進に有用で あるとして勧められている。その理由として，こ の強度の運動であれば長時間の持続が可能，血中 乳酸值の持続的増加がみられない,アシドーシス

\footnotetext{
1)オムロン株式会社 ヘルスケアビジネスカンパニー テ615-0084 京都市右京区山ノ内山ノ下町24番地

2) 京都大学大学院 人間. 環境学研究科 于606-8501 京都市左京区吉田二本松町

${ }^{3)} \mathrm{JT}$ 京都専売病院 内科 干605-0932 京都市東山区東大路涉谷下る

4) 京都大学大学院 医学研究科 内分泌. 代謝内科学: 于606-8507 京都市左京区聖護院川原町54
}

Omron Corporation Healthcare Company, 24, Yamanouchi Yamanoshita-cho, Ukyo-ku. Kyoto, 615-0084, Japan The Graduate School of Human and Environmental Studies, Kyoto University, Sakyo-ku, Kyoto, 606-8501, Japan Kyoto Senbai Hospital, 447, Myouhouinmaekawa-cho, Higashiyama-ku, Kyoto, 605-0932. Japan

Department of Medicine and Clinical Science, Kyoto University Graduate School of Medicine, 54, Shogoin Kawahara-cho, Sakyo-ku, Kyoto, 606-8507, Japan 
の危険性が少ない, 運動強度の増加に対して心 機能の応答が保たれているといった点が挙げら $れ^{10)}$, 心疾患 ${ }^{29)}$, 高血圧症 ${ }^{31)}$, 糖尿病 ${ }^{14)}$ などの 有疾患患者に対してもそのトレーニング効果が報 告されている. また, 最大酸素捸取量 $\left(\mathrm{V}_{2} \mathrm{max}\right)$ の測定のように最大までの運動を必要とするので はなく, 最大下の運動負荷から求められる点も VT あるいは LT が勧められている理由の一つと して考えられる. 特に, 高強度の運動による生体 への負担を考えると, 運動強度を決定するためで あっても，できるだけ低強度での運動負荷からの 決定が望ましいと考えられる。しかしながら， LT の測定は観血的であったり，VTの測定には 高価な装置が必要であったりするなどの理由か ら，その測定は病院や大学などの専門施設に限ら れており，一般のトレーニング施設などでは，ほ とんど実施されていないのが現状である。そのた め, 一般的には 220 から年齢を差し引くなどの推 定式を用いて算出した予測最大心拍数に一定の係 数を乗じて運動時の目標心拍数を決定する方法 ${ }^{2)}$ を用いている場合が多い。この方法は特別な検査 を実施せず,簡易に運動強度を決定できるものの, 同じ年齢であれば設定される運動時の心拍数も同 じになり，個人の体力レベルや健康状態が反映さ れていないという問題点がある.また，心拍数な どの測定を行わずに運動強度を決定する方法とし て、「楽〜ややきつい」と感じる程度の運動など 運動中の自覚症状に基ついた Borg 指数 ${ }^{4)}$ も実際 の運動療法の現場で多く用いられている.しかし, この方法も実施者が Borg 指数の表現法に慣れて いなかったり，説明が不十分であったりするなど の理由により, 運動中の Borg 指数が過小評価さ れるという問題がある ${ }^{2)}$.このように，それぞれ の簡便な運動強度決定方法には問題点があり, 特 に高齢者では最大心拍数の個人差が大きく，冠動 脈疾患のリスクも高いため ${ }^{2)}$, 運動強度の設定の 際には注意が必要となる。そのため, 個人に適し た運動強度をより簡便で高強度の運動負荷を必要 とせずに設定する方法が求められている。

一方, 運動強度の増加に伴って心拍数が増加す る生理的メカニズムを自律神経応答の面から明ら
かにする試みとして, 運動負荷変化と心拍変動と の関係が検討されている．パワースペクトル解析 を用いて漸増負荷運動中の心拍変動を解析した報 告では, 高周波 $(\mathrm{HF})$ 成分が運動開始から強度の 増加とともに急激に減少したことが報告されてい $3^{16 \sim 20,27,28,34)}$. さらに HF 成分の消失後に $\mathrm{VT}$ が出現し, その後, HF 成分と低周波 (LF) 成 分の比 $(\mathrm{LF} / \mathrm{HF})$ の増加が認められたという報告 もあり 16.20.34), 心臓自律神経活動の応答とVT との関連性が示唆されている. また, Tulppo ら ${ }^{30)}$ は，パワースペクトル解析による HF 成分だけで なく, Poincare plotから得られる SDl および隣 り合った心拍間隔の差の標準偏差から求められる SDsd が副交感神経の薬理ブロックによって消失 し，漸増負荷運動時にはVTに達するまで有意 に減少し，それ以降はほとんど消失していたと報 告している。ささらに，一定時間内の心拍間隔の標 準偏差を平均值で除して100を乗じることで求め られる CVRRは運動強度の増加に伴い50\% $\dot{\mathrm{V}} \mathrm{O}_{2} \max$ 強度までは著しく低下し, それより強い 運動では低下がわずかであったことが報告されて いる7).このように, VT 前後の強度において副 交感神経活動を反映する指標の消失が認められて $お り$, 漸増負荷運動時の副交感神経活動の消失レ ベルからVTあるいはVTに近い運動強度が得 られる可能性が示唆されている.

心臓自律神経活動の評価に用いられる心拍間隔 の測定は, 高価な機器を必要とせず, 非観血的に, かつ容易に計測が可能である。 そのため, 運動中 の自律神経活動の変化からVTもしくはVTに 近い運動強度が決定できれば，より簡易に個人の 体力レベルに応じた至適運動強度を提供できる可 能性が考えられる。 そこで, 本研究では心臓自律 神経活動の変化を利用して, トレーニング時の至 適運動強度を決定する方法を開発し，さらに， VT および年齢に基づく運動時の目標心拍数設定 法との比較から, 本方法の信頼性を明らかにする ことを目的とした。

\section{II. 方法}

対象は, 12歳から65歳までの健康な男女総数79 
名を対象として，以下の方法で実施した。

最初に，心拍変動の解析に基づいた VTに相 当する運動強度の判定基準を設定する目的で，事 前の健康スクリーニング(問診)で問題がないと判 断された健常者, 男性 9 名 $(35.7 \pm 15.5$ 歳), 女性 7 名 (33.0 0 6.8歳)の計16名を対象として下記の 運動負荷テストを施行した。次いで, 幅広い年齢 層において心拍変動の解析から判定した運動強度 の信頼性を確認するため, 10歳台 8 名, 20歳台11 名, 30歳台14名, 40歳台19名, 50歳台 6 名, 60歳 台 5 名の男女計63名を対象として, 同様の運動負 荷を施行した。

\section{A. 運動負荷テスト}

測定に先立ち，被験者には前日からの激しい運 動, 薬物の服用を禁じ, 測定前 3 時間の飲食を避 けるよう指示した。

運動負荷はコンビ社製の自転車エルゴメータ 232CXL を用いた. 5 分間の座位安静の後, 15 wattで 2 分間のウォーミングアップを行い, 表 1 に示す年齢と体重の属性で決定した負荷変動率 に基づくランプ負荷を60回転/分のペダル回転速 度で行った.負荷の増加は, 運動中の心拍数が 220 一年齢によって計算した年齢予測最大心拍数 (HRmax)の $80 \%$ に至るまで続けた.

テスト中の換気諸量およびガス交換諸量は Sensor Medics 社製の呼吸代謝測定装置 Vmax 用い, breath-by-breath での測定を行った。呼気 ガス分析の結果から，換気性作業間值 (VT)を $\mathrm{V}$-slope 法 $^{3)}$ に基づいて決定し, VT 出現時の心

Table 1. Ramp exercise protocol.

\begin{tabular}{cccc}
\hline $\begin{array}{c}\text { Age } \\
\text { (year) }\end{array}$ & $\begin{array}{c}\text { Weight } \\
(\mathrm{kg})\end{array}$ & Male & Female \\
\hline & $<40$ & $10 \mathrm{~W} / \mathrm{min}$ & $5 \mathrm{~W} / \mathrm{min}$ \\
$<60$ & $<80$ & $15 \mathrm{~W} / \mathrm{min}$ & $10 \mathrm{~W} / \mathrm{min}$ \\
& $\geqq 80$ & $20 \mathrm{~W} / \mathrm{min}$ & $15 \mathrm{~W} / \mathrm{min}$ \\
$\geqq 60$ & All & $10 \mathrm{~W} / \mathrm{min}$ & $5 \mathrm{~W} / \mathrm{min}$ \\
\hline
\end{tabular}

拍数および酸素摂取量を求めた.

\section{B．心拍変動の解析}

テスト中の心電図は日本光電社製のマルチテレ メータシステム WEB-5000により, 胸部双極誘 導によって導出した。 心拍間隔は, 実時間で10ビ ットの A/D 変換を用いて $4 \mathrm{msec}(250 \mathrm{~Hz})$ で心電 図 R 波をサンプリングし，独自に開発したコンピ ユータプログラムによってリアルタイム処理にて 検出した。また，心拍間隔データをバッチ処理形 式にて, 式 1 を用いて心拍間隔変動值 (the mean of the sum of the squared differences in successive R-R intervals；MSSD)を15秒ごとに求めた.

$$
\mathrm{MSSD}_{\mathrm{n}}=\left[\Sigma\left(\mathrm{RR}_{\mathrm{n}}-\mathrm{RR}_{\mathrm{n}-1}\right)^{2} / \mathrm{N}\right]\left(\mathrm{msec}^{2}\right)
$$

これは，単位計測時間 (30秒間)に観察された互 いに隣り合う心拍間隔 $(\mathrm{RR})$ の差の自乗の合計值 を，単位計測時間に観察された心拍間隔の個数 (N)で除すことで求めた平均值で，1 心拍間隔あ たりの心拍変動の大きさを示している. 我々の先 行研究 ${ }^{26)}$ における薬理ブロック実験結果より, 同様の手法にて計算した心拍間隔変動値は pro. pranolol 投与による交感神経ブロックにより有意 に増加し， atropine 投与による副交感神経ブロッ クにより消失しており，心臓副交感神経活動を反 映する指標であることが示されている.

この心拍間隔変動値の運動中のトレンドをリア ルタイムで捉える方法として，連続する 3 点の データから，現在に近い值ほど大きなウェイトを かけて計算する加重移動平均処理

$$
\begin{aligned}
{\left[\mathrm{X}_{\mathrm{n}}=\right.} & \left(\mathrm{MSSD}_{\mathrm{n}-2}+\mathrm{MSSD}_{\mathrm{n}-1} \times 2\right. \\
& \left.\left.+\mathrm{MSSD}_{\mathrm{n}} \times 3\right) / 6\right]
\end{aligned}
$$

を行った。

\section{C. 統計解析}

データの值はすべて平均士標準偏差で示した. また，各变数間の関係はピアソンの相関分析を用 い，統計的有意水準はすべて危険率 $5 \%$ 未満とし た。 
III. 結

\section{果}

A . 心拍変動の解析に基づいた VT に相当する 運動強度 ( $T_{\text {HRV }}$ )の判定基準の設定

図 1 にランプ負荷運動中における心拍間隔変動 值の変化の代表例を示した。 心拍間隔変動値はラ ンプ負荷運動開始から指数関数的に減少し VT 近傍で収束したが，この傾向はすべての被験者で 同様に認められた。このことから，各個人の心拍 間隔変動值の収束点を,VTレベルにおける心拍 間隔変動值との関連で検討した。

図 2 に 15 watt でのウォーミングアップ時，お よび VTを基準とした各運動強度での心拍間隔 変動值の平均值を示した。 ウォーミングアップ時 では $673.9 \pm 604.1 \mathrm{msec}^{2}$ と高值を示し, 運動強 度の増加に伴って減少し, $100 \% \mathrm{VT}$ 強度では,

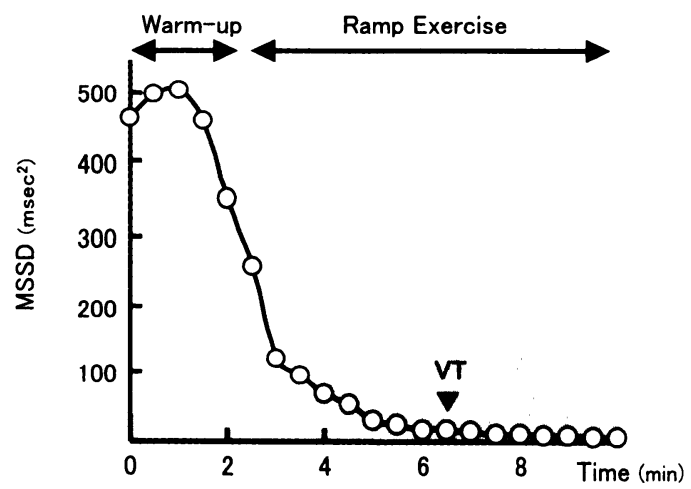

Fig. 1. Representative time course of change in heart rate variability during ramp exercise. MSSD : the mean of the sum of squared differences in successive RR intervals, VT : ventilatory threshold.

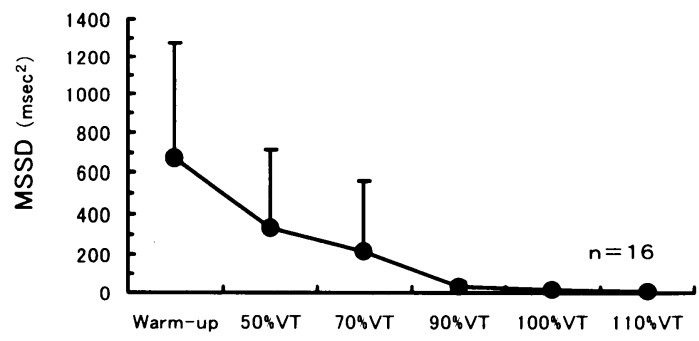

Fig. 2. Effect of exercise intensity on MSSD during ramp exercise.

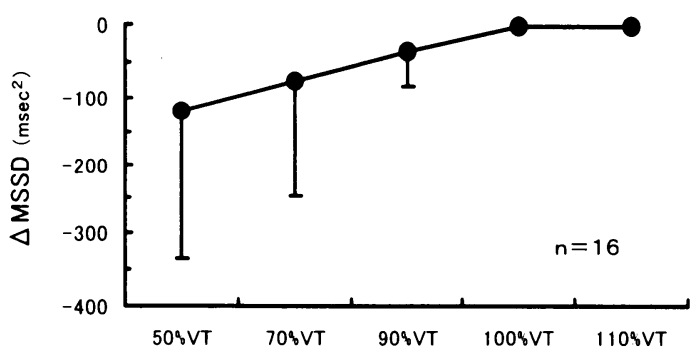

Fig. 3. Effect of exercise intensity on $\triangle M S S D$ $\left(\mathrm{MSSD}_{n}-\mathrm{MSSD}_{\mathrm{n}-1}\right)$ during ramp exercise.

$19.3 \pm 4.9 \mathrm{msec}^{2}$ であった。このように，VT 時 にはウォーミングアップ時の $2.9 \%$ にまで減少し ており，その值は個人によってややばらつきが認 められたが, 全例 $25 \mathrm{msec}^{2}$ 以下の值であった。 また，110\%VT 強度では $12.1 \pm 4.3 \mathrm{msec}^{2}$ であ り, VTを超えるとほとんど変化がなくなった。

次に, VT を基準とする各運動強度での 1 つ前 の心拍間隔変動值との差 $\left(\triangle M S S D: M_{\text {SSD }}-\right.$ $\left.\mathrm{MSSD}_{\mathrm{n}-1}\right)$ を算出し, 図 3 に示した。 その結果, 運動初期の 50\% V T 強度ではー $119.4 \pm 215.9$ $\mathrm{msec}^{2}$ と大きな減少を示していたが, 運動強度の 増加に伴う絶対值の低下とともに，その変化量も 小さくなった. $100 \% \mathrm{VT}$ 強度では， $-2.8 \pm 2.5$ $\mathrm{msec}^{2}$ とほとんど変化が認められない者からやや 低下傾向を示す者までおり, 最も大きい变化量の 絶対值は $6 \mathrm{msec}^{2}$ であった。

これらの結果より, 心拍間隔変動值が 25 $\mathrm{msec}^{2}$ を下回り, その変化量が $6 \mathrm{msec}^{2}$ 以下とな るという条件を 2 回連続で満たした時点を心拍間 隔変動值の収束, すなわち, 心拍変動の解析から 判定したVTに相当する運動強度 (heart rate variability threshold : $\left.T_{\text {IIRV }}\right)$ とした。

\section{B. $T_{\text {HRV }}$ の信頼性の検討}

次いで, 計63名の男女を対象として運動負荷テ ストを実施し，それぞれの $\mathrm{T}_{\mathrm{HRV}}$ とVTを決定 し，両者を比較検討することによって $\mathrm{T}_{\mathrm{HRV}}$ の 信頼性を検証した． $\mathrm{T}_{\mathrm{HRV}}$ での心拍数 $\left(\mathrm{T}_{\mathrm{HRV}}-\mathrm{HR}\right)$ および体重あたりの酸素拱取量 $\left(\mathrm{T}_{\mathrm{HRV}}-\mathrm{V}_{2} / \mathrm{wt}\right)$ はそれぞれ111.8土13.2拍/分, $15.2 \pm 4.4 \mathrm{ml} / \mathrm{kg}$ / 分であった。一方, 呼気ガス分析から求めたVT 

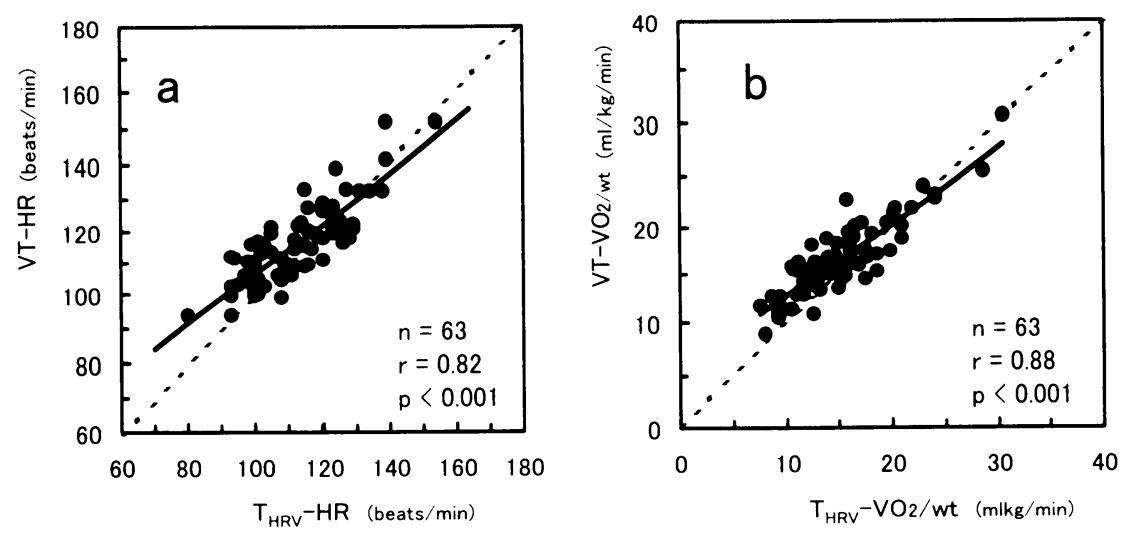

Fig. 4. Correlation between heart rate variability threshold $\left(\mathrm{T}_{\text {IIRV }}\right)$ and $\mathrm{VT} ; \mathrm{a}$ : heart rate $(\mathrm{HR}), \mathrm{b}$ : oxygen uptake $\left(\dot{\mathrm{V}}_{2} / \mathrm{wt}\right)$

出現時の心拍数 (VT-HR)および体重当たりの酸

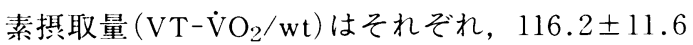
拍/分， $16.5 \pm 3.7 \mathrm{ml} / \mathrm{kg} /$ 分であった。

図 4 -a にVT-HR と $\mathrm{T}_{\mathrm{IIRV}}-\mathrm{HR}$ との関係を, 図 4 -bにVT- $\mathrm{VO}_{2} / \mathrm{w}$ tと $\mathrm{T}_{\mathrm{HRV}}-\dot{\mathrm{VO}}_{2} / \mathrm{wt}$ との関 係を示した.VTと $\mathrm{T}_{\mathrm{HRV}}$ との関係は, 心拍数お よび $\mathrm{V}_{2} / \mathrm{wt}$ のどちらの検討においても $\mathrm{r}=0.82$ $(\mathrm{p}<0.001), r=0.88(\mathrm{p}<0.001)$ とそれぞれ統計 的に有意な相関関係が認められた。

また，従来から多く用いられている年齢に基づ く運動時の目標心拍数設定法の妥当性を検討する ため, VT 強度に相当すると考えられる HRmax の $65 \%$ 強度の心拍数 $(65 \% \mathrm{HRmax})$ を目標心拍数と

して設定し，VT-HR との関係について図 5 に示 した。その結果, 65\%HRmax と VT-HR との間 には有意な相関関係が認められた $(\mathrm{r}=0.50, \mathrm{p}<$ $0.001)$.

さらに，それぞれの関係について詳細に検討す るため，10歳台から60歳台までの各年代における $\mathrm{T}_{\text {IIRV }}$-HR と VT-HR, 65\%HRmax と VT-HR と の相関係数を算出し, 表 2 に示した.VT-HR と $\mathrm{T}_{\text {IIRV }}$-HR との関係については, $\mathrm{r}=0.75 \sim 0.88$ $(p<0.05 \sim 0.001)$ とすべての年代において有意 な相関関係が認められた。しかし,VT-HRと 65\%HRmax との関係についてみると，すべての 年代に扔いて有意な相関関係が認められなかった $(r=0.09 \sim 0.50$, N. S. $)$.

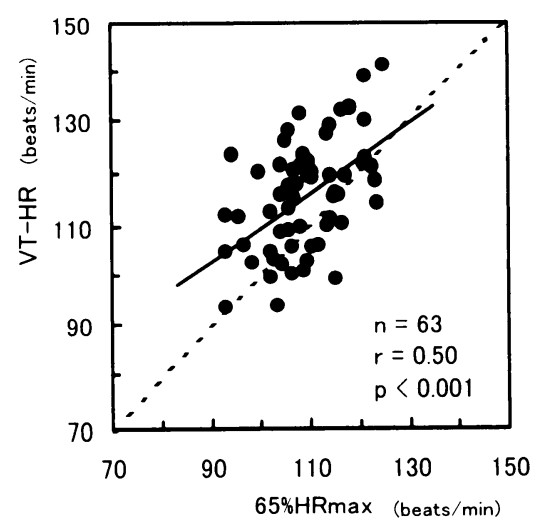

Fig. 5. Correlation between $65 \%$ value of agepredicted maximal heart rate $(65 \% H R$ max $)$ and VT-HR.

\section{N. 考察}

心拍変動の解析方法は，大きく分けて周波数領 域での解析方法と時間領域での解析方法とがあ $\eta^{8)}$ ，近年では周波数領域での解析方法であるパ ワースペクトル解析を用いた検討が多くなされて いる16ー20.24.27.28.34). しかし、パワースペクト ル解析ではデー夕の定常性が必要であり ${ }^{21)}$, 呼 吸パターンの変化による影響を受けるため ${ }^{5,9)}$,

ランプ負荷運動中の心臓自律神経活動の評価に は不適との意見もある。これに対して, Penttila $ら^{23)}$ は時間領域での解析方法はデー夕の定常性 を必要とせず，呼吸パターンの变化による影響を 
Table 2. Correlation coefficiencies (R) of VT-HR vs. $65 \% H R \max$ and $\mathrm{T}_{\mathrm{HRV}}-\mathrm{HR}$ in different age groups.

\begin{tabular}{cccccc}
\hline Age Group & $\mathrm{N}$ & $\begin{array}{c}\text { Age } \\
\text { (year) }\end{array}$ & $\begin{array}{c}\text { Weight } \\
(\mathrm{kg})\end{array}$ & $\begin{array}{c}\mathrm{R} \\
\text { vs. 65\%HRmax }\end{array}$ & $\begin{array}{c}\mathrm{R} \\
\text { vs. } \mathrm{T}_{\mathrm{HRV}} \text {-HR }\end{array}$ \\
\hline 10 's & 8 & $16.3 \pm 2.4$ & $52.6 \pm 11.3$ & 0.09 & $0.81 * *$ \\
20 's & 11 & $26.4 \pm 2.1$ & $64.5 \pm 12.0$ & 0.17 & $0.83 * *$ \\
30 's & 14 & $36.4 \pm 3.5$ & $65.7 \pm 12.8$ & 0.31 & $0.85 * *$ \\
40 's & 19 & $44.0 \pm 2.8$ & $71.5 \pm 12.8$ & 0.43 & $0.75 * *$ \\
50 's & 6 & $53.2 \pm 3.8$ & $52.9 \pm 3.1$ & 0.04 & $0.88 *$ \\
60 's & 5 & $63.8 \pm 1.8$ & $61.2 \pm 6.8$ & 0.50 & $0.81 *$ \\
\hline & & & & &
\end{tabular}

受けないため, 運動時の心臓自律神経活動の評価 に適していると報告している。さらに，パワース ペクトル解析に比較して時間領域での解析は計算 量が非常に少なく，リアルタイムで処理を行う場 合など，高速な処理が求められる際に非常に有利 である，そこで本研究では心臓自律神経活動の評 価指標として，時間領域での解析方法を用いた。

また，本研究では近年トレーニング強度の設定 の際に用いられ，その運動効果が多く確認されて いるVTを至適運動強度と考え，非観血的に高 価な装置を用いることなく至適運動強度を決定す ることを目的とし，運動中の心拍間隔の解析に基 づいてVTに相当する運動強度 $\left(\mathrm{T}_{\text {IIRV }}\right)$ を決定し た。心拍間隔変動值 $(M S S D)$ のトレンドを捉える ため，現在の值に近いほど大きなウェイトをかけ て算出する加重移動平均処理を行った。データの トレンドを捉える代表的な方法としては，全デー 夕を用いて近似曲線を当てはめる方法も考えられ るが，本研究では運動中にリアルタイムで心拍間 隔変動值のトレンドを捉えるため, 加重移動平均 処理を用いた。また，ランプ負荷運動中における VT 強度での心拍間隔変動值は全例 $25 \mathrm{msec}^{2}$ 以 下であり，その変化量は全例 $6 \mathrm{msec}^{2}$ 以下であっ たため, (1)心拍間隔変動值が $25 \mathrm{msec}^{2}$ 以下, (2) 心拍間隔変動值の変化が $6 \mathrm{msec}^{2}$ 以下, という両 条件を満たした時点を心拍変動の解析から判定し たVTに相当する運動強度 $\left(\mathrm{T}_{\mathrm{HRV}}\right)$ とした。ここ
で，両条件に用いる值をVT 時に得られたそれ ぞれ最大值としたが，VT 時の心拍間隔変動值が 低值であり, 変化量が小さい者ではこの決定条件 をそのまま用いると $\mathrm{T}_{\mathrm{HRV}}$ がVTに比較して低 い強度で決定されてしまう。また，両条件に用い る值を本実験で得られた平均值に設定すると， VT 時の心拍間隔変動值が高值であり, その変化 量が大きい者は $\mathrm{T}_{\mathrm{HRV}}$ がVTに比較してかなり 高い強度で決定され，中には $\mathrm{T}_{\mathrm{IRV}}$ が決定でき ない場合が考えられる。さらに，運動強度の増加 に伴う心拍間隔变動値の変化は，必ずしも単調減 少ではなく，一旦減少した後に上昇し，その後ま た減少するといったような変動を示す例も認めら れた。そのため，決定条件に用いる值はそれぞれ 本実験で得られたVT 時の最大值に設定し, (1) と(2)の条件を2 回連続で満たした時点を $\mathrm{T}_{\mathrm{HRV}}$ として決定した。

これに対して，心拍間隔の変動がなくなる心臓 への自律神経支配を遮断した際 ${ }^{1)}$ の心拍間隔変動 值に基づき，ランプ負荷運動時に心拍間隔変動值 が自律神経遮断時の值に達したレベルを $\mathrm{T}_{\mathrm{HRV}}$ とする方法も考えられる。しかし, 自律神経遮断 時の心拍数は年齢 ${ }^{13)}$ や心筋の機能 ${ }^{12)}$ などの違い によって異なり，さらに個々の自律神経遮断時の 心拍間隔変動值を求めるとなると薬剤の投与が必 要となる ${ }^{1)}$ な゙の理由から実用的ではないと考 え, VTとの比較から統計的手法によって $\mathrm{T}_{\mathrm{HRV}}$ 
を決定した。その結果， $\mathrm{T}_{\mathrm{HRV}}$ はVTと強い相関 関係を示し，本方法によってVTに近い運動強 度を決定することができた。高橋 ${ }^{28)} は$ は、ランプ 負荷運動中における心拍変動スペクトル解析を行 い, HF 成分の低下の程度が変わる変化点を求め た結果，VT と近い酸素摂取量值を示したが，相 関は認められなかったと報告している。また， Moritani $\check{5}^{16)} も$, 漸増負荷連動中の HF 成分の 消失はVTと同時もしくは先行していたと報告 しており，必ずしも HF 成分の消失点はVTと 一致していないことも考えられる。このように， 心拍変動の解析からどのように運動強度を決定す るかによって結果は異なり，心臓自律神経活動の 変化から VTに近い運動強度を決定するために は，本研究で実施したようなVTに合わせる決 定アルゴリズムを作成する必要があると考えられ る.

一方，従来から多く用いられている年齢に基づ いた目標心拍数ではVTとの相関が低く，さら に年代ごとに検討するとすべての年代で相関関係 が認められなかった．年齢に基づく心拍数設定法 の問題点としては, HRmax を年齢のみ变数とし て算出している点が挙げられる。山口吕の報告 によると実測最大心拍数は加齢によって低下する ものの, 同じ年齢であっても土20拍/分以上の個 人差が認められている。さらに，トレーニングを 行っている連動選手では一般健常者に比較して最

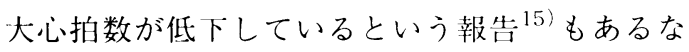
ど，年龄以外に影響を及ぼしている要因もあると 考えられる. Dwyer ${ }^{6)}$ はトレーニングを行ってい る健常者群, 心疾患者群, トレーニングを行って いない健常者群, 心疾患者群の 4 群に分け, 最大 心拍数に対するVT 時の心拍数の割合が，それ ぞれの群で異なっていたと報告している。このよ うに同じ年齢であっても最大心拍数にはばらつき があり，最大心拍数に対するVT時の心拍数の 割合も異なるため, 年齢に基づいた統計的手法で 心拍数を設定するよりも，個々の特性に心じた運 動強度の設定が望ましいと考えられる。

また本研究では，VTの決定のために $80 \%$ HRmax 強度まで運動負荷を実施したが, T IIRV
の決定では $\mathrm{T}_{\mathrm{HRV}}$ までの運動負荷, すなわち 61.8 土6.0\%HRmax までの運動によって決定できた. VTレベルでは, 有酸素的代謝による $\mathrm{CO}_{2}$ 産生 に加えて重炭酸系による乳酸の緩衝作用の結果と しての $\mathrm{CO}_{2}$ 産生が重畳され，また，この緩衝作 用の結果, 生じた水素イオン $\left(\mathrm{H}^{+}\right)$が澒動脈体を 刺激して換気ドライブを直進させて運動中の換気 量が增す32り。これにより，VTはガス交換諸量の 変曲点から決定できるが，変曲点を検出するため には，その前後のデータが必要となり，変曲点を 中心とした広い範井でのデータがあるほど検出が 容易となる、V-slope 法を用いてVT を決定する 場合, $\dot{\mathrm{VO}}_{2}$ に対する $\dot{\mathrm{V} C \mathrm{C}_{2}}$ の上昇度が变化する 点からVT が求められるが, 変曲点となる VT レベルよりも高強度での運動時のデータが少ない ほど，VTの決定が困難となる。当然ながら，運 動器の障害があったり被験者の努力不足などで VT以上の運動負荷が実施されなかった場合に は, VTは決定できない11)。一般的には，VTの 決定を行う場合, $\mathrm{VO}_{2}$ が負荷量の増加に対して 直線的に上昇し始める点から呼吸性代償が始まる respiratory compensation $(\mathrm{RC})$ ポイントまでの デー夕を解析に用い, その間のデータから得ら れた 2 つ回帰直線の交点からVT が決定され る11!。そのため, 呼吸性代償が始まる $\mathrm{RC}$ ポイ ントが $90 \% \mathrm{VO}_{2} \mathrm{max}$ 付近で出現することを考え ると ${ }^{22)}$, ガス交換諸量の変曲点から求めるVT の決定には, 疲労困侅に至るまで運動を実施しな くても最大に近い強度までの運動負荷の実施が必 要となると思われる。これに対して，本研究では 運動中の心拍変動をリアルタイムで解析し，その 収束点を決定することで, VT の決定時よりもよ り低い運動負荷から安全に運動強度の決定が可能 となった。

なお，今回の研究は若年から初老期の健常者を 対象として検討を行ったのみであり，有疾患者や 高齿者への適応は今後の課題である. 実際, 心不 全患者では心拍変動スペクトル解析による HF 成 分が, 健常者に比較して安静時から低值を示し, 運動による低下はわずかなことが報告されてい る25)。また, 糖尿病患者においても HF 成分は 
健常者に比較して安静時から低值であり, 漸増負 荷運動によって減衰したが絶対的変化が小さいこ とが報告されている ${ }^{17)}$ 。このような患者に対し ても，本研究で得られた基準を用いてVTに相 当する運動強度の決定が可能かどうかには今後の 慎重な検討が必要である。

\section{V.まと め}

\section{ランプ負荷運動中における心拍変動の解析から} 判定した $T_{H R V}$ は, 健常者における検討で, 各 個人のVTレベル相当の運動強度を提示すること が示唆された。 $\mathrm{T}_{\mathrm{IIRV}}$ による運動強度の決定の利 点として, 呼気ガス分析装置などの高価な機器を 用いずに運動強度設定が可能なこと, 非観血的な 心拍間隔の計測のみから決定できること, VT の 決定よりも低い強度の運動負荷試験によって決定 が可能であることが挙げられたＶVTが健康増進 のための運動強度として推奨されていることか ら, $\mathrm{T}_{\mathrm{IRV}}$ も VT と同様に至適運動強度の指標と して有用と考えられた。

\section{(受理日 平成15年 3 月 31 日)}

\section{参考文献}

1) Akselrod S, Gordon D, Ubel FA, Shannon DC, Barger AC, and Cohen RJ. Power spectrum analysis of heart rate fluctuation : a quantitative probe of beat-by-beat cardiovascular control. Science, (1981), 213, 220-222.

2) アメリカスポーツ医学協会編 (日本体力医学会体力 科学編集委員会監訳), 運動処方の指針 原著第 6 版, 南光堂, 東京, (2001)

3) Beaver W L, Wasserman K, and Whipp B J. A new method for detecting the anaerobic threshold by gas change. J Appl Physiol, (1986). 60, 2020-2027.

4) Borg G A. Psychophysical bases of perceived exertion. Med Sci Sports, (1982), 14, 377-387.

5) Brown T E, Beightol L A, Koh J, and Eckberg D L. Important influence of respiration on human $R-R$ in. terval power spectra is largely ignored. J Appl Phy. siol, (1993), 75, 2310-2317.

6) Dwyer J. Metabolic character of exercise at tradi. tional training intensities in cardiac patients and healthy persons. J Cardiopulmonary Rehabil, (1994), 14. 189-196.

7）藤井宣晴, 鍋倉賢治, 権 五星, 山崎文夫, 本間 幸子, 池上晴夫. 運動強度の增大に対する心拍数 および血槳カテコールアミンの応答. 体力科学,
(1992), 41, 313-321.

8) 早野順一郎. 心拍変動解析 (1) 一時間領域と周波数 領域の指標-. Therapeutic Reserch，(1996)，17, 53-60.

9) Hirsch J A and Bishop B. Respiratory sinus arrhythmia in humans : how breathing pattern mod. ulates heart rate. Am J Physiol, (1981), 241, H620$\mathrm{H} 629$.

10）伊東春樹. A T を基準とした運動療法. 呼と循, (1992)，40, 1173-1182.

11）伊東春樹。呼気ガス分析によるAT 測定，谷口興 一編, 心肺連動負荷テスト, 第 1 版, 南汇堂, 東京, (1993), 155-164.

12) Jose A D and Taylor R R. Autonomic blockade by propranolol and atropine to study intrinsic myocar. dial function in man. J Clin Invest, (1969), 48, 2019-2031.

13) Jose A D and Collison D. The normal range and determination of the intrinsic heart rate in man. Cardiovasc Res, (1970), 4, 160-167.

14) Kawaji K, Fujita Y, Yamaji Y, Shirataka M, and Kubo H. Usefulness of anaerobic threshold in estimating intensity of exercise for diabetics. Diabetes Res Clin Pract, (1989), 6, 303-309.

15) Lester F M, Sheffield L T, and Reeves T J. Factors affecting maximal heart rate during extreme exer. cise. Ala J Med Sci, (1969), 6, 42-45.

16) Moritani T, Hayashi T, Shinohara M, Mimasa F, and Shibata M. Comparison of sympatho-vagal function among diabetic patients, normal controls and endur. ance athletes by heart rate spectral analysis. J Sports Med Sci, (1993), 7, 31-39.

17）森谷敏夫, 林達也, 桝田出, 中尾一和, 篠原 稔, 見正富美子, 柴田真志. 安静時および運動負 荷時における糖尿病患者の自律神経活動一心拍変 動スペクトル解析による比較検討一。プラクティ 又別冊 9 月，(1994），78-84.

18）中村好男, 玉木啓一, 篠原稔, 木村裕一, 村岡功. 漸増真荷運動中の心拍摇動パワースペクトルの推 移. 体力科学, (1989), 38, 208-214.

19）中村好男，木村裕一，玉木啓一，村岡 功。運動 時心迷走神経活動の指標としての呼吸性心拍変動 の評価.ヒューマンサイエンス, (1990), 3, 33-39.

20）中村好男, 山本義春. 健康の維持・増進のための 適正な運動強度の探索 一自律神経系拮抗調節か らみた無酸素性作業間値の実用上の意義について の検討一。体力研究，(1991)，77, 82-91.

21）大坂元久, 齋藤宽和. 心拍变動解析のための装置 とその解析方法. 外山淳治 渡邊佳彦 編 時空 間心電情報の新しい視点, ライフメディコム 愛 知, (1998), 318-334.

22) Oshima Y. Miyamoto T, Tanaka S, Wadazumi T, Kurihara N, and Fujimoto $S$. Relationship between isocapnic buffering and maximal aerobic capacity in athletes. Eur J Appl Physiol, (1997), 76, 409-414.

23) Penttila J, Helminen A, Jartti $T$, Kuusela T, Huikuri 
H V, Tulppo M P, Coffeng R, and Scheinin H. Time domain, geometrical and frequency domain analysis of cardiac vagal outflow : effects of various respira. tory patterns. Clin Physiol, (2001), 21, 365-376.

24) Perini R, Milesi S, Fisher N M, Pendergast D R, Veicsteinas A. Heart rate variability during dyna. mic exercise in elderly males and females. Eur J Appl Physiol, (2000), 82, 8-15.

25）佐藤廣, 山本真千子, 安部七郎, 矢部彰久, 飯 沼宏之, 相澤忠範, 加藤和三。穴不全者におけ る運動中の白律神経活動の変化. 自律神経, (1994), 31, 14-20.

26) Shibata M, Moritani T, Miyawaki T, Hayashi $T$, and Nakao K. Exercise prescription based upon cardiac vagal activity for middle-aged obese women. Int J Obesity, (2002), 26, 1356-1362.

27）铪谷満, 林由紀子, 関川清一, 川口浩太郎, 大成 浄志, 小林和典. 運動中の心拍変動と換気性作業 閾値との関連－MemCalc法による検討一(第一 報). 体力科学, (2001)，50，185-192.

28）高橋光彦. 換父性作業䦨做前後における筋電図挹 よび心電図 RR 間隔変動のスペクトル解析による 運動特性に関する研究。北海道医誌，(1999)，74，
$7-18$.

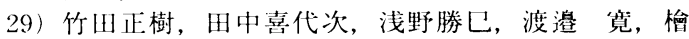
山輝男. Lactate Threshold を用いた冠動脈疾患患 者用の運動プログラムのあり方．呼と循，（1993）， 41, 999-1003.

30) Tulppo M P, Makikallio T H, Takala T E S, Sep. panen T, and Huikuri H V. Quantitative beat-bybeat analysis of heart rate dynamics during exer. cise. Am J Physiol, (1996), 271, H244-H252.

31) Urata $H$, Tanabe $Y$, Kiyonaga A, Ikeda M, Tanaka $\mathrm{H}$, Shindo M, and Arakawa K. Antihypertensive and volume-depleting effects of mild exercise on essen. tial hypertension. Hypertension, (1987), 9, 245-252.

32) Wasserman K, Whipp B J, Koyal S N, and Cleary M $G$. Effect of carotid body resection on ventilatory and acid-base control during exercise. J Appl Phy. siol, (1975). 39, 354-358.

33）山口一郎，運動負荷に対する生理的生体反応と運 動負荷試騃. Coronary，(1989)，6，12-18.

34) Yamamoto Y. Hughson R L, and Peterson J C. Autonomic control of heart rate during exercise studied by heart rate variability spectral analysis. J Appl Physiol, (1991), 71, 1136-1142. 